\title{
KEEFEKTIFAN MODEL PEMBELAJARAN INOVATIF DENGAN MENGGUNAKAN MIND MAPPING DALAM PEMBELAJARAN MENULIS NARASI SISWA SD
}

\author{
Lilik Binti Mirnawati \\ Universitas Muhammadiyah Surabaya \\ lilikbintimirnawati@fkip.um-surabaya.ac.id
}

Diterima: 1 November 2018

Publikasi: 27 Februari 2019

DOI: http://dx.doi.org/10.32528/bb.v4i1.1868

\begin{abstract}
ABSTRAKS
Tujuan dalam penelitian ini adalah untuk mengetahui keefektifan model pembelajaran inovatif dengan menggunakan mind mapping dalam pembelajaran menulis narasi siswa kelas IISD. Keefektifan pembelajaran dapat dilihat dari hasil observasi aktivitas siswa selama kegiatan pembelajaran, sedangkan peningkatan keterampilan menulis karangan narasi siswa dapat dilihat dari hasil tes pada uji coba terbatas dan uji coba luas. Hasil penelitian yang telah dilakukan menunjukkan bahwa keefektifan model pembelajaran inovatif dengan menggunakan mind mapping dalam pembelajaran menulis narasi siswa kelas II SD sangat baik. Hal ini dapat dilihat berdasarkan rekapitulasi hasil observasi aktivitas siswa pada uji coba terbatas dan uji coba luas berada pada presentasi $81 \%-100 \%$ yang berarti sangat baik. Selanjutnya, berdasarkan hasil rekapitulasi peningkatan keterampilan menulis narasi siswa kelas II SD menunjukkan hasil bahwa siswa dapat meningkatkan keterampilan menulis narasi siswa. Hasil rekapitulasi peningkatan keterampilan menulis narasi siswa kelas II SD pada uji coba terbatas sebesar 21,97\%, dan pada uji coba luas sebesar 19,68\%.
\end{abstract}

Kata Kunci: Model Pembelajaran Inovatif, Mind Mapping, Menulis Narasi

\begin{abstract}
The purpose of this study was to determine the effectiveness of innovative learning models using mind mapping in learning to write narratives of second grade Elementary School students. The effectiveness of learning can be seen from the results of observations from students 'activities during learning activities, while the improvement of students' narrative essay writing skills can be seen from the results of tests on limited trials and extensive trials. The results of the research that have been conducted show that the effectiveness of innovative learning models using mind mapping in learning to write narratives of second grade Elementary School students is very good. This can be seen based on the recapitulation of observations of student activities in limited trials and extensive trials at presentations of $81 \%-100 \%$ which means very good. Furthermore, based on the results of the recapitulation, the improvement of narrative writing skills of the second grade students showed the results that students could improve the students' narrative writing skills. The results of the recapitulation of the improvement of the narrative writing skills of the second grade elementary school students in the limited trial were $21.97 \%$, and the extensive trial was $19.68 \%$.
\end{abstract}

Keywords: Innovative Learning Model, Mind Mapping, Narrative Writing

\section{PENDAHULUAN}

Pembelajaran bahasa Indonesia di

sekolah dasar dalam Kurikulum 2013

menjadi pusat integrasi dari mata pelajaran IPA dan IPS. Penguatan peran

mata pelajaran bahasa Indonesia
dilakukan secara utuh melalui
penggabungan sebagian kompetensi


dasar mata pelajaran IImu Pengetahuan Sosial dan Ilmu Pengetahuan Alam ke dalam mata pelajaran Bahasa Indonesia(KEMENDIKBUD, 2013). Pelajaran bahasa Indonesia dalam Kurikulum 2013 berbasis teks. Pembelajaran berbasis teks idealnya dari memahami teks, mengolah teks, mendiskusikan teks, dan diakhir memproduksi teks. Dengan pembelajaran berbasis teks, siswa menggunakan bahasa tidak saja hanya disajikan sebagai sarana komunikasi, tetapi sebagai sarana mengembangkan kemampuan berpikir. Penekanan baca-tulis menjadikan mata pelajaran bahasa Indonesia memiliki peran dan kedudukan yang utama di sekolah dasar.

Keterampilan berbahasa Indonesia meliputi empat jenis, yaitu menyimak, berbicara, membaca, dan menulis. (Nurgiyantoro, 2009) menyatakan bahwa dibanding ketiga keterampilan lain, keterampilan menulis lebih sulit dikuasai oleh penutur bahasa yang bersangkutan, karena menulis melibatkan berbagai keterampilan yang memerlukan penguasaan unsur kebahasaan, kemampuan menyusun perasaan dan pikiran dengan menggunakan kata-kata dalam bentuk kalimat agar menghasilkan karangan yang runtut dan padu sesuai dengan kaidah-kaidah tata bahasa.

Menulis merupakan kegiatan yang komplek karena penulis dituntut untuk dapat menyusun dan mengorganisasikan isi tulisan serta menuangkannya dalam ragam bahasa tulis (Dalman, 2014). Hal ini senada dengan pendapat bahwa "Writing is an activity of expressing feelings in written language in order to entertain, convey, explain, or tell something to someone" (Mirnawati, 2017).Menurut (Gorys Keraf, 2008)narasi merupakan salah satu bentuk tulisan yang berusaha mengisahkan suatu kejadian atau peristiwa sehingga tampak seolah-olah pembaca melihat atau mengalami sendiri peristiwa tersebut.Dari pendapat tersebut dikatehui bahwa menulis narasi merupakan kegiatan menuangkan perasaan dalam bahasa tulis dengan tujuan ingin menghibur, menyampaikan, menjelaskan, atau memberitahukan sesuatu kepada seseorang. Oleh sebab itu, keterampilan menulis khusunya menulis narasi harus dikembangkan dan diupayakan peningkatannya. Namun pada kenyataannya kemampuan menulis siswa SD saat ini belum sesuai dengan kompetensi yang diharapkan dalam kurikulum.

Hasil observasi yang telah peneliti lakukan pada siswa kelas II SD di SDN Kalijudan I/239 Surabaya menunjukkan bahwa siswa masih belum menguasai kompetensi dasar tentang menulis narasi. Siswa masih enggan untuk menuangkan ide atau pikiran mereka dalam bentuk tulisan. Penyebab kurang tertariknya siswa dalam pembelajaran menulis khususnya menulis narasi adalah model pembelajaran guru yang diterapkan selama ini belum bisa meningkatkan motivasi siswa dalam menulis khususnya menulis narasi.

Alternatif yang dapat digunakan untuk mengatasi permasalahan tersebut adalah dengan menerapkan model pembelajaran inovatif dengan menggunakan mind 
mapping dalam pembelajaran menulis narasi. Model pembelajaran tersebut dapat meningkatkan potensi internal siswa, peran aktif siswa, dan dengan menggunakan mind mapping akan membantu siswa untuk memudahkan menuangkan ide atau pikirannya ke dalam bentuk tulisan

Mind mapping atau pemetaan pikiran merupakan cara yang sangat baik untuk menghasilkan dan menata gagasan sebelum mulai menulis (Hernowo, 2004).Pemetaan pikiran adalah teknik pemanfaatan seluruh otak dengan menggunakan citra visual dan prasarana grafis lainnya untuk membentuk kesan(De Porter, 2001). Otak seringkali mengingat informasi dalam bentuk gambar, simbol, suara, bentuk-bentuk, dan perasaan.

Model pembelajaran adalah pola dalam merancang pembelajaran, dapat juga didefinisikan sebagai langkah pembelajaran dan perangkatnya untuk mencapai tujuan pembelajaran(Akbar, 2013). Model pengelolaan kelas yang mendukung dalam pengembangan model pembelajaran inovatif ini adalah pembelajaran kooperatif, dan pembelajaran berbasis masalah (PMB).

Menurut Artzt dan Newman "dalam belajar kooperatif siswa belajar bersama sebagai suatu tim dalam menyelesaikan tugas-tugas kelompok untuk mencapai tujuan bersama"(Trianto, 2011).Menurut Arends "pengajaran berdasarkan masalah merupakan suatu pendekatan pembelajaran dimana siswa mengerjakan permasalahan yang autentik dengan maksud untuk menyusun pengetahuan mereka sendiri, mengembangkan inkuiri dan percaya diri" (Trianto, 2012). Kedua model tersebut masih memiliki kelemahan jika digunakan dalam kegiatan pembelajaran bahasa Indonesia secara mandiri, sehingga perlu adanya inovasi dalam mengembangakan model pembelajaran inovatif yang dapat meningkatkan keterampilan menulis narasi siswa kelas II SD.

Berdasarkan pernyataan tersebut, maka rumusan masalah yang dapat dirumuskan dalam penelitian yang bertujuan secara umum adalah untuk mengetahui keefektifan model pembelajaran inovatif dengan menggunakan mind mapping dalam pembelajaran menulis narasi siswa kelas II SD. Secara khusus tujuan dalam penelitian ini adalah untuk (1) mengetahui keefektifan model pembelajaran inovatif dengan menggunakan mind mapping dalam pembelajaran menulis narasi siswa kelas II SD berdasarkan aktivitas siswa, (2) mengetahui keefektifan model pembelajaran inovatif dengan menggunakan mind mapping dalam pembelajaran menulis narasi siswa kelas II SD berdasarkan peningkatan keterampilan menulis narasi siswa.

\section{METODE PENELITIAN}

Ditinjau dari aspek tujuan penelitian, metode yang digunakan dalam penelitian ini menggunakan penelitian kuantitatif, sedangkan teknik analisis data yang digunakan adalah statistik deskriptif. Teknik analisis statistik deskriptif digunakan untuk menganalisis data dengan cara mendeskripsikan atau menggambarkan data yang telah 
Lilik Binti Mirnawati. Keefektifan Model Pembelajaran....

Jurnal Belajar Bahasa, ISSN 2502-5864, E-ISSN 2503-0329

Volume 4, No. 1, Februari 2019

terkumpul sebagaimana adanya tanpa

bermaksud membuat kesimpulan yang

berlaku untuk umum atau

generalisasi(Sugiyono, 2009).Pada

penelitian ini teknik analisis statistik deskriptif direalisasikan dengan menjumlahkan skor dari jawaban atau tanggapan terhadap angket.

Berdasarkan variabel yang diteliti, peneliti menggunakan dua teknik pengumpulan data yaitu observasi dan tes. Teknik observasi digunakan untuk mengetahui aktivitas siswa kelas II SD selama proses pembelajaran menulis narasi melalui model pembelajaran inovatif dengan menggunakan mind mapping pada saat uji coba terbatas maupun uji coba luas. Instrumen yang digunakan untuk menganalisis data keefektifan model pembelajaran berdasarkan lembar observasi pengamat, digunakan instrumen penganalisisan data sebagai berikut.

Tabel 1 Instrumen Penganalisisan Data Keefektifan Model Pembelajaran yang Dikembangkan Berdasarkan Hasil Pengamatan Aktivitas Siswa

\begin{tabular}{|c|c|c|c|c|}
\hline \multirow{2}{*}{ No. } & \multirow{2}{*}{ Aspek Penilaian } & \multicolumn{2}{|c|}{ Persentase(\%) } & \multirow{2}{*}{$\begin{array}{l}\text { Rata- } \\
\text { rata }\end{array}$} \\
\hline & & P1 & P2 & \\
\hline 1 & \begin{tabular}{|l|} 
Kesiapan siswa untuk \\
melaksanakan pembelajaran
\end{tabular} & & & \\
\hline 2 & $\begin{array}{l}\text { Minat belajar siswa ketika } \\
\text { melakukan kegiatan } \\
\text { pembelajaran }\end{array}$ & & & \\
\hline 3 & $\begin{array}{l}\text { Kerjasama siswa dalam } \\
\text { kelompok }\end{array}$ & & & \\
\hline 4 & $\begin{array}{l}\text { Menyimak penjelasan guru } \\
\text { terkait materi yang dipelajari }\end{array}$ & & & \\
\hline 5 & $\begin{array}{l}\text { Kemandirian siswa dalam } \\
\text { menulis }\end{array}$ & & & \\
\hline 6 & \begin{tabular}{|l|} 
Ketertiban siswa selama \\
pembelajaran berlangsung
\end{tabular} & & & \\
\hline 7 & $\begin{array}{l}\text { Menjawab pertanyaan } \\
\text { umpan balik yang diberikan } \\
\text { guru }\end{array}$ & & & \\
\hline 8 & $\begin{array}{l}\text { Keaktifan siswa dalam } \\
\text { melakukan kegiatan }\end{array}$ & & & \\
\hline
\end{tabular}

\begin{tabular}{|l|l|l|l|}
\hline \multicolumn{1}{|l|}{$\begin{array}{l}\text { menyimpulkan materi } \\
\text { pembelajaran }\end{array}$} & & & \\
\hline Jumlah skor & & & \\
\hline Rata-rata & & & \\
\hline Keaktifan(\%) & & & \\
\hline
\end{tabular}

Keterangan:

$\mathrm{P} 1$ : pengamat 1

$\mathrm{P} 2$ : pengamat 2

Selanjutnya, teknik tes digunakan untuk mengetahuipeningkatan keterampilan menulis narasi siswa kelas II SD. Teknik tes ini dilakukan pada uji coba terbatas dan uji coba luas. Pada setiap uji coba diberlakukan ter awal (pre-test) dan tes akhir (post-test). Instrumen yang digunakan adalah lembar kerja siswa menulis narasi, lembar rubrik penilaian menulis narasi, dan lembar hasil penilaian menulis narasi. Instrumen yang digunakan untuk menganalisis data keefektifan model pembelajaran berdasar peningkatan keterampilan menulis siswa, digunakan instrumen pada table 2 .

Prosedur penganalisis data tentang keefektifan model pembelajaran inovatif dengan menggunakan mind mapping diperoleh dari lembar observasi aktivitas siswa, dan lembar penilaian menulis narasi. Prosedur untuk menganalisis data keefektifan model pembelajaran berdasarkan lembar observasi.

Tabel 2 Instrumen Penganalisisan Data Model Pembelajaran berdasarkan Peningkatan Keterampilan Menulis Narasi Siswa

\begin{tabular}{|r|l|l|l|l|l|l|}
\hline \multirow{2}{*}{ No } & \multirow{2}{*}{ Nama Siswa } & \multicolumn{2}{|c|}{ N } & \multirow{2}{*}{ PHB } & \multirow{2}{*}{ K } & KK \\
\hline & & U1 & U2 & & & \\
\hline 1 & & & & & & \\
\hline 2 & & & & & & \\
\hline 3 & & & & & & \\
\hline Jumlah & & & & & \\
\hline \multicolumn{2}{|l|}{ Rata-rata } & & & & & \\
\hline
\end{tabular}




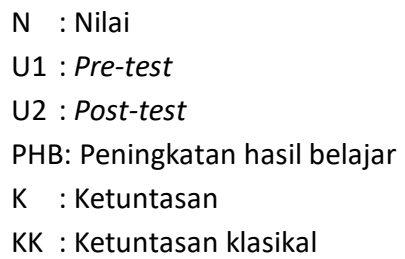

Prosedur penganalisisan data sebagai berikut.

(1) Mengumpulkan data

(2) Mengklasifikasikan data

(3) Menghitung data berdasarkan rumus:

Nilai Presentase $=\frac{\text { jumlah skor yang diperoleh }}{\text { jumlah skor tertinggi } x \text { jumlah pertanyaan }} \times 100$

(4) Mentranformasikan data berdasarkan kriteria interpretasi skor:

Tabel 3Kriteria Interpretasi Skor

\begin{tabular}{|c|c|}
\hline Skala Penilaian & Kriteria \\
\hline $0-20 \%$ & Sangat kurang \\
\hline $21-40 \%$ & Kurang baik \\
\hline $41-60 \%$ & Cukup baik \\
\hline $61-80 \%$ & Baik \\
\hline $81-100 \%$ & Sangat baik \\
\hline
\end{tabular}

(5) Menentukan tingkat kepraktisan model pembelajaran yang dikembangkan berdasarkan aktivitas siswa

(6) Menyimpulkan data.

Selanjutnya, untuk menganalisis data keefektifan model pembelajaran berdasar peningkatan keterampilan menulis narasi siswa, digunakan prosedur penganalisisan data sebagai berikut:

1. Mengumpulkan data

2. Melakukan rekapitulasi data yang telah diperoleh

3. Mengubah jenis data (disesuaikan dengan teknik analisis yang akan digunakan)
4. Mengolah data yang diperoleh menggunakan statistik deskriptif dengan rumus:

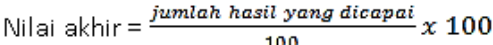

Untuk mengetahui peningkatan keterampilan menulis diperoleh dari hasil penilaian keterampilan menulis siswa yang dianalisis secara statistik deskriptif berdasarkan kriteria penilaian penulisan narasi dari perbedaan pre-test dan hasil tulisan narasi pada saat penerapan model pembelajaran yang dikembangkan (posttest).

\section{PEMBAHASAN}

Keefektifan model pembelajaran dapat dilihat dari penilaian hasil pengamatan aktivitas siswa selama proses pembelajaran dan peningkatan keterampilan menulis narasi siswa yang dilihat dari hasil pre-test dan post-test pada uji coba terbatas maupun uji coba luas. Berdasarkan hasil penelitian menunjukkan bahwa keefektifan model pembelajaran inovatif dengan menggunakan mind mapping dalam pembelajaran menulis narasi siswa kelas II SD sangat baik. Hal ini dapat dilihat berdasarkan hasil rekapitulasi aktivitas siswa dan peningkatan keterampilan menulis narasi siswa. Secara rinci dapat dijabarkan sebagai berikut.

\section{Aktivitas Siswa}

Subjek penelitian uji coba adalah siswa kelas II SDN Kalijudan I Surabaya sebanyak 62 siswa. Siswa kelas II A sebanyak 31 siswa yang digunakan untuk uji coba terbatas, sedangkan siswa kelas II B 
sebanyak 31 siswa yang digunakan untuk uji coba luas. Pelaksanaan penelitian terdiri dari satu pertemuan pre-test dan satu pertemuan pelaksanaan kegiatan pembelajaran dengan menggunakan model pembelajaran yang dikembangkan.

Aktivitas siswa pada saat pelaksanaan kegiatan belajar mengajar berlangsung diamati oleh dua orang pengamat dengan menggunakan instrumen lembar pengamatan aktivitas siswa. Pengamatan terhadap aktivitas siswa dilakukan terhadap individu setiap anak ketika proses pembelajaran dan aktivitas dalam kelompok, dari awal hingga akhir kegiatan pembelajaran berlangsung secara seksama. Pengamatan dilakukan pada uji coba terbatas dan uji coba luas. Hasil pengamatan aktivitas siswa uji coba terbatas di kelas II A SDN Kalijudan I Surabaya secara rinci dapat dilihat pada Tabel 4 sebagai berikut.

Tabel 4RekapitulasiHasil PengamatanAktivitas Siswa (Uji Coba Terbatas)

\begin{tabular}{|c|c|c|c|c|}
\hline \multirow{2}{*}{ No. } & \multirow{2}{*}{$\begin{array}{c}\text { Aspek yang } \\
\text { Dinilai }\end{array}$} & \multicolumn{2}{|c|}{ Skor } & \multirow{2}{*}{$\begin{array}{l}\text { Rata- } \\
\text { rata }\end{array}$} \\
\hline & & P1 & P2 & \\
\hline 1 & $\begin{array}{l}\text { Kesiapan siswa } \\
\text { untuk } \\
\text { melaksanakan } \\
\text { pembelajaran }\end{array}$ & 4 & 4 & 4 \\
\hline 2 & $\begin{array}{l}\text { Minat belajar } \\
\text { siswa ketika } \\
\text { melakukan } \\
\text { kegiatan } \\
\text { pembelajaran }\end{array}$ & 4 & 4 & 4 \\
\hline 3 & $\begin{array}{l}\text { Kerjasama siswa } \\
\text { dalam kelompok }\end{array}$ & 3 & 4 & 3,5 \\
\hline 4 & $\begin{array}{l}\text { Menyimak } \\
\text { penjelasan guru } \\
\text { terkait materi } \\
\text { yang dipelajari }\end{array}$ & 4 & 4 & 4 \\
\hline 5 & $\begin{array}{l}\text { Kemandirian } \\
\text { siswa dalam } \\
\text { menulis narasi }\end{array}$ & 4 & 4 & 4 \\
\hline 6 & $\begin{array}{l}\text { Ketertiban siswa } \\
\text { selama } \\
\text { pembelajaran } \\
\text { berlangsung }\end{array}$ & 4 & 3 & 3,5 \\
\hline
\end{tabular}

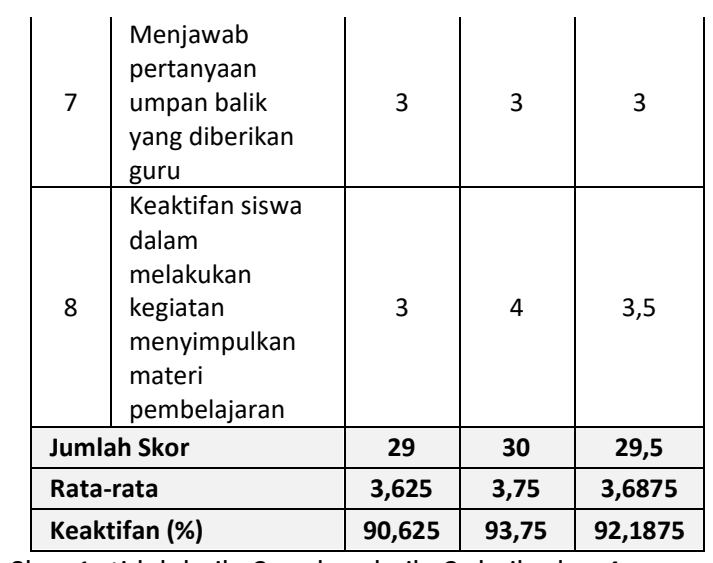

Skor 1: tidak baik, 2: cukup baik, 3: baik, dan 4: sangat baik

Keterangan:

P1 : pengamat 1

$\mathrm{P} 2$ : pengamat 2

Pengamatan aktivitas siswa terdiri dari delapan komponen penilaian. Komponen pengamatan aktivitas siswa yang pertama yaitu kesiapan siswa untuk melaksanakan pembelajaran mendapatkan skor 4 dari pengamat 1 dan 2 yang artinya sangat baik. Aktivitas yang kedua yaitu minat belajar siswa ketika melakukan kegiatan pembelajaran mendapat skor 4 dari pengamat 1 dan 2 yang berarti sangat baik. Aktivitas siswa yang ketiga adalah kerjasama siswa dalam kelompok mendapat skor penilian 3 dari pengamat 1 yang berarti baik, sedangkan dari pengamat 2 mendapatkan skor penilaian 4 yang berarti sangat baik. Aktivitas siswa yang keempat yaitu menyimak penjelasan guru terkait materi yang dipelajari mendapat skor 4 yang berarti baik dari pengamat 1 dan pengamat 2 .

Selanjutnya, aktivitas siswa kelima yaitu kemandirian siswa dalam menulis narasi mendapatkan skor penilaian 4 dari masing-masing pengamat yang berarti sangat baik. Aktivitas keenam yaitu 
Jurnal Belajar Bahasa, ISSN 2502-5864, E-ISSN 2503-0329

Volume 4, No. 1, Februari 2019

ketertiban siswa selama pembelajaran berlangsung mendapat skor penilaian 4 yang berarti sangat baik dari pengamat 1 dan skor 3 dari pengamat 2 yang berarti baik. Aktivitas ketujuh menjawab pertanyaan umpan balik yang diberikan guru mendapat skor penilaian 3 dari pengamat 1 dan pengamat 2 yang berarti baik. Aktivitas kedelapan yaitu keaktifan siswa dalam melakukan kegiatan menyimpulkan materi pembelajaran mendapat skor penilaian 3 pengamat 1 yang berarti baik dan skor 4 dari pengamat 2 yang berarti sangat baik.

Dari keseluruhan analisis data pengamatan aktivitas siswa dalam proses pembelajaran uji coba terbatas seperti yang terlihat pada Tabel 3 tersebut, ratarata skor pengamatan aktivitas siswa dari pengamat 1 adalah 3,625 dengan persentase keaktifan $90,625 \%$, dan skor rata-rata dari pengamat 2 adalah sebesar 3,75 dengan persentase keaktifan $93,75 \%$, sehingga skor rata-rata yang didapat dari pengamat 1 dan pengamat 2 adalah 3,6875 dengan persentase keaktifan 92,1875\%. Dengan demikian dapat disimpulkan bahwa aktivitas siswa kelas II A SDN Kalijudan I Surabaya selama megikuti pelajaran dengan menggunakan model pembelajaran yang dikembangkan dapat dikategorikan sangat baik.

Di samping itu, hasil pengamatan aktivitas siswa uji coba luas di kelas II B SDN Kalijudan I Surabaya secara rinci dapat dilihat pada Tabel 5 sebagai berikut.

Tabel 5RekapitulasiHasil PengamatanAktivitas Siswa (Uji Coba Luas)

\begin{tabular}{|l|l|l|l|}
\hline No. & Skor & \\
\hline
\end{tabular}

\begin{tabular}{|c|c|c|c|c|}
\hline & $\begin{array}{l}\text { Aspek yang } \\
\text { Dinilai }\end{array}$ & P1 & P2 & $\begin{array}{c}\text { Rata- } \\
\text { rata }\end{array}$ \\
\hline 1 & $\begin{array}{l}\text { Kesiapan siswa } \\
\text { untuk } \\
\text { melaksanakan } \\
\text { pembelajaran }\end{array}$ & 4 & 4 & 4 \\
\hline 2 & $\begin{array}{l}\text { Minat belajar } \\
\text { siswa ketika } \\
\text { melakukan } \\
\text { kegiatan } \\
\text { pembelajaran }\end{array}$ & 4 & 4 & 4 \\
\hline 3 & $\begin{array}{l}\text { Kerjasama siswa } \\
\text { dalam kelompok }\end{array}$ & 3 & 4 & 3,5 \\
\hline 4 & $\begin{array}{l}\text { Menyimak } \\
\text { penjelasan guru } \\
\text { terkait materi } \\
\text { yang dipelajari }\end{array}$ & 4 & 4 & 4 \\
\hline 5 & $\begin{array}{l}\text { Kemandirian } \\
\text { siswa dalam } \\
\text { menulis }\end{array}$ & 4 & 4 & 4 \\
\hline 6 & $\begin{array}{l}\text { Ketertiban siswa } \\
\text { selama } \\
\text { pembelajaran } \\
\text { berlangsung }\end{array}$ & 4 & 3 & 3,5 \\
\hline 7 & $\begin{array}{l}\text { Menjawab } \\
\text { pertanyaan } \\
\text { umpan balik yang } \\
\text { diberikan guru }\end{array}$ & 3 & 4 & 3,5 \\
\hline 8 & $\begin{array}{l}\text { Keaktifan siswa } \\
\text { dalam melakukan } \\
\text { kegiatan } \\
\text { menyimpulkan } \\
\text { materi } \\
\text { pembelajaran }\end{array}$ & 3 & 4 & 3,5 \\
\hline \multicolumn{2}{|c|}{ Jumlah Skor } & 29 & 31 & 30 \\
\hline \multicolumn{2}{|c|}{ Rata-rata } & 3,625 & 3,875 & 3,75 \\
\hline \multicolumn{2}{|c|}{ Keaktifan (\%) } & 90,625 & 96,875 & 93,75 \\
\hline
\end{tabular}

Skor 1: tidak baik, 2: cukup baik, 3: baik, dan 4: sangat baik

Keterangan:

P1 : pengamat 1

$\mathrm{P} 2$ : pengamat 2

Kategori pengamatan aktivitas siswa pada uji coba luas terdiri dari delapan komponen. Komponen pengamatan aktivitas siswa yang pertama yaitu kesiapan siswa untuk melaksanakan pembelajaran mendapatkan skor 4 dari pengamat 1 dan 2 yang artinya sangat baik. Aktivitas yang kedua yaitu minat belajar siswa ketika melakukan kegiatan pembelajaran mendapat skor 4 dari pengamat 1 dan 2 yang berarti sangat baik. Aktivitas siswa yang ketiga adalah kerjasama siswa dalam kelompok 
mendapat skor penilian 3 dari pengamat 1 yang berarti baik dan skor 4 dari pengamat 2 yang berarti sangat baik. Aktivitas siswa yang keempat yaitu menyimak penjelasan guru terkait materi yang dipelajari mendapat skor 4 yang berarti sangat baik dari pengamat 1 dan pengamat 2 .

Selanjutnya, aktivitas siswa kelima yaitu kemandirian siswa dalam menulis karangan narasi mendapatkan skor penilaian 4 dari masing-masing pengamat yang berarti sangat baik. Aktivitas keenam yaitu ketertiban siswa selama pembelajaran berlangsung mendapat skor penilaian 4 dari pengamat 1 yang berarti sangat baik, sedangkan dari pengamat 2 mendapatkan skor penilaian 3 yang berarti baik. Aktivitas ketujuh menjawab pertanyaan umpan balik yang diberikan guru mendapat skor penilaian 3 dari pengamat 1 yang berarti baik dan skor 4 dari pengamat 2 yang berarti sangat baik. Aktivitas kedelapan yaitu keaktifan siswa dalam melakukan kegiatan menyimpulkan materi pembelajaran mendapat skor penilaian 3 dari pengamat 1 yang berarti baik dan skor 4 dari pengamat 2 yang berarti sangat baik.

Dari keseluruhan analisis data pengamatan aktivitas siswa dalam proses pembelajaran uji coba luas seperti yang terlihat pada Tabel 4 tersebut, rata-rata skor pengamatan aktivitas siswa dari pengamat 1 adalah 3,625 dengan persentase keaktifan 90,625\%, dan dari pengamat 2 adalah sebesar 3,875 dengan persentase keaktifan 96,875\%, sehingga skor rata-rata yang didapat dari pengamat 1 dan pengamat 2 adalah 3,75 dengan persentase keaktifan 93,75\%. Dengan demikian dapat disimpulkan bahwa aktivitas siswa kelas II B SDN Kalijudan I Surabaya selama megikuti pelajaran dengan menggunakan model pembelajaran yang dikembangkan dapat dikategorikan sangat baik.

Berdasarkan rekapitulasi hasil pengamatan aktivitas siswa pada uji coba terbatas dan uji coba luas mendapatkan persentase keaktifan antara $81 \%-100 \%$, artinya aktivitas siswa selama menerapkan model pembelajaran yang dikembangkan sangat baik. Hal ini menunjukkan bahwa keefektifan model pembelajaran yang dikembangkan berdasarkan aktivitas siswa selama proses pembelajaran pada kelas II SDN Kalijudan I Surabaya adalah sangat baik.

\section{Peningkatan keterampilan menulis narasi siswa}

Untuk mengetahui peningkatan kemampuan menulis siswa kelas II SDN Kalijudan I Surabaya pada uji coba terbatas dan uji coba luas dilakukan tes menulis narasi sebanyak dua kali, yaitu satu kali sebelum penerapan model pembelajaran dan satu kali ketika penerapan model pembelajaran yang dikembangkan. Hasil penilaian menulis narasi siswa sebelum dan ketika penerapan model pemebelajaran yang dikembangkan pada uji coba terbatas dapat disajikan secara detail pada Tabel 6 berikut.

Tabel 6RekapitulasiHasil Tes Menulis Narasi (Uji Coba Terbatas)

\begin{tabular}{|l|c|c|c|c|c|c|}
\hline \multirow{2}{*}{ No. } & \multirow{2}{*}{ Nama } & \multicolumn{2}{|c|}{ N } & \multirow{2}{*}{ PHB } & K & $\begin{array}{c}\text { KK } \\
\text { (\%) }\end{array}$ \\
\cline { 3 - 4 } & U1 & U2 & & & \\
\hline
\end{tabular}




\begin{tabular}{|c|c|c|c|c|c|c|}
\hline 1 & $\begin{array}{l}\text { Alishiya Aulia } \\
\text { Putri }\end{array}$ & 54 & 78 & 24 & $\mathrm{~T}$ & U2 : Post-test \\
\hline 2 & $\begin{array}{l}\text { Amelia Julia } \\
\text { Lismana }\end{array}$ & 70 & 80 & 10 & $\mathrm{~T}$ & $\begin{array}{l}\text { PHB : Peningkatan hasil belaj } \\
\mathrm{K} \quad \text { : Ketuntasan }\end{array}$ \\
\hline & Annisa & & & & & KK . Kotuntacan klacik \\
\hline
\end{tabular}

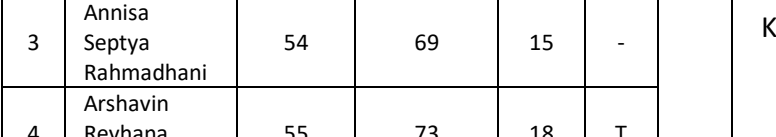

\begin{tabular}{|c|l|c|c|c|c|}
\hline 4 & $\begin{array}{l}\text { Arshavin } \\
\text { Reyhana } \\
\text { Raflyansyah }\end{array}$ & 55 & 73 & 18 & $\mathrm{~T}$ \\
\hline 5 & Baby Berlian & 52 & 78 & 26 & $\mathrm{~T}$ \\
\hline 6 & $\begin{array}{l}\text { Dafha Eko } \\
\text { Nugroho }\end{array}$ & 71 & 87 & 16 & $\mathrm{~T}$ \\
\hline
\end{tabular}

\begin{tabular}{|c|l|c|c|c|c|}
\hline 7 & $\begin{array}{l}\text { Daffa Zainul } \\
\text { Muttaqin }\end{array}$ & 58 & 87 & 29 & $\mathrm{~T}$ \\
\hline 8 & $\begin{array}{l}\text { Destiani Putri } \\
\text { Ayuningtyas }\end{array}$ & 54 & 70 & 16 & $\mathrm{~T}$ \\
\hline & Dina Farichah & 56 & 57 & 1 & \\
\hline
\end{tabular}

\begin{tabular}{|c|l|c|c|c|c|}
\hline 9 & $\begin{array}{l}\text { Dina Farichah } \\
\text { Chafidz }\end{array}$ & 56 & 57 & 1 & - \\
\hline 10 & $\begin{array}{l}\text { Dona } \\
\text { Romadoni }\end{array}$ & 56 & 75 & 19 & $\mathrm{~T}$ \\
\hline 11 & Famad Dany & 53 & 71 & 18 & $\mathrm{~T}$ \\
\hline
\end{tabular}

\begin{tabular}{|c|l|c|c|c|c|}
\hline 11 & $\begin{array}{l}\text { Farhad Dany } \\
\text { Firmansyah }\end{array}$ & 53 & 71 & 18 & $\mathrm{~T}$ \\
\hline 12 & $\begin{array}{l}\text { Ferdiansyah } \\
\text { Putra Abadi }\end{array}$ & 54 & 89 & 35 & $\mathrm{~T}$ \\
\hline
\end{tabular}

\begin{tabular}{|c|l|c|c|c|c|}
\hline 12 & $\begin{array}{l}\text { Ferdiansyah } \\
\text { Putra Abadi }\end{array}$ & 54 & 89 & 35 & $\mathrm{~T}$ \\
\hline 13 & $\begin{array}{l}\text { Firman Jaya } \\
\text { Laksana }\end{array}$ & 54 & 85 & 31 & $\mathrm{~T}$ \\
\hline 14 & Galang & 47 & 70 & 23 & $\mathrm{~T}$ \\
\hline
\end{tabular}

\begin{tabular}{|c|l|c|c|c|c|}
\hline 14 & $\begin{array}{l}\text { Galang } \\
\text { Maulana }\end{array}$ & 47 & 70 & 23 & $\mathrm{~T}$ \\
\hline 15 & $\begin{array}{l}\text { Hafizh Rizky } \\
\text { Kurniawan }\end{array}$ & 47 & 69 & 22 & - \\
\hline 16 & $\begin{array}{l}\text { Ken Sutta } \\
\text { Wuragil }\end{array}$ & 57 & 90 & 33 & $\mathrm{~T}$ \\
\hline 17 & $\begin{array}{l}\text { M. Fariz } \\
80\end{array}$ \\
\cline { 1 - 4 }
\end{tabular}

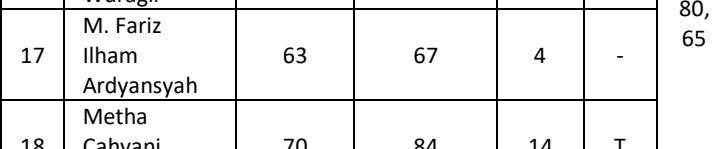

\begin{tabular}{|c|c|c|c|c|c|}
18 & $\begin{array}{l}\text { Metha } \\
\text { Cahyani } \\
\text { Maulidia }\end{array}$ & 70 & 84 & 14 & $\mathrm{~T}$ \\
\hline 19 & $\begin{array}{l}\text { Michell Dista } \\
\text { Chafinda }\end{array}$ & 53 & 69 & 16 & - \\
\hline
\end{tabular}

\begin{tabular}{|c|c|c|c|c|}
\hline 19 & $\begin{array}{l}\text { Michell Dista } \\
\text { Chafinda }\end{array}$ & 53 & 69 & 16 \\
\hline 20 & $\begin{array}{l}\text { Moch. Reza } \\
\text { Prasetyo }\end{array}$ & 54 & 83 & 29 \\
\hline
\end{tabular}

\begin{tabular}{|c|l|l|l|l|c|}
21 & $\begin{array}{l}\text { Muhammad } \\
\text { Dimas } \\
\text { Pramata }\end{array}$ & 64 & 90 & 26 & $\mathrm{~T}$ \\
\hline Putri Amelia & 53 & 93 & 40 & $\mathrm{~T}$ \\
\hline
\end{tabular}

\begin{tabular}{|c|l|c|c|c|c|}
\hline 22 & $\begin{array}{l}\text { Putri Amelia } \\
\text { Lestari }\end{array}$ & 53 & 93 & 40 & $\mathrm{~T}$ \\
\hline 23 & $\begin{array}{l}\text { Rafika Aulia } \\
\text { Ferdianti }\end{array}$ & 57 & 86 & 29 & $\mathrm{~T}$ \\
\hline
\end{tabular}

\begin{tabular}{|c|c|c|c|c|c|}
\hline 23 & Ferdianti & 57 & 86 & 29 & $\mathrm{~T}$ \\
\hline 24 & $\begin{array}{l}\text { Raga Aditya } \\
\text { Firmansyah } \\
\text { A. }\end{array}$ & 55 & 89 & 34 & $\mathrm{~T}$ \\
\hline 25 & $\begin{array}{l}\text { Rasya Rizky } \\
\text { Syaputra }\end{array}$ & 54 & 90 & 36 & $\mathrm{~T}$ \\
\hline
\end{tabular}

\begin{tabular}{|c|c|c|c|c|c|}
\hline 26 & $\begin{array}{l}\text { Risyad Ridho } \\
\text { Karunia }\end{array}$ & 54 & 87 & 33 & T \\
\hline 27 & Safira Dwi & 47 & 87 & 40 & T \\
\hline
\end{tabular}

\begin{tabular}{|c|l|c|c|c|c|}
\hline 27 & $\begin{array}{l}\text { Safira Dwi } \\
\text { Adistira }\end{array}$ & 47 & 87 & 40 & $\mathrm{~T}$ \\
\hline 28 & $\begin{array}{l}\text { Syahlendra } \\
\text { Jalu Alzabani } \\
\text { Setiadi }\end{array}$ & 47 & 70 & 23 & $\mathrm{~T}$ \\
\hline
\end{tabular}

\begin{tabular}{|c|l|c|c|c|c|}
\hline 29 & Setiadi & & & & \\
\hline 30 & $\begin{array}{l}\text { Viky Arianto } \\
\text { Agustinahma }\end{array}$ & 57 & 58 & 1 & - \\
\hline 31 & $\begin{array}{l}\text { Yuwita Sari } \\
\text { Anggraeni }\end{array}$ & 63 & 71 & 8 & $\mathrm{~T}$ \\
\hline \multicolumn{2}{|c|}{ Jumlah } & $\mathbf{1 7 4 6}$ & $\mathbf{2 4 2 7}$ & $\mathbf{6 8 1}$ & \\
\hline & Rata-rata & $\mathbf{5 6 , 3 2 2 5}$ & $\mathbf{7 8 , 2 9 0 3 2 3}$ & $\begin{array}{c}\mathbf{2 1 , 9} \\
\mathbf{6 7 7 4}\end{array}$ & \\
\hline
\end{tabular}

Keterangan:

$\mathrm{N}$ : Nilai

U1 : Pre-test
Berdasarkan Tabel 6 diketahui bahwa hasil tes menulis uji coba terbatas yang dilakukan pada siswa kelas II A SDN Kalijudan I Surabaya diperoleh data yaitu, nilai rata- rata siswa pada pre-test ialah 56,32 dan terdapat 28 diantara 31 siswa yang tidak mencapai standar ketuntasan sekolah, sehingga yang mencapai standar ketuntasan minimal sebanyak tiga anak. Setelah penerapan model pembelajaran yang dikembangkan, skor capaian nilai rata-rata siswa pada post-test menulis narasi ialah 78,29, dan terdapat 6 diantara 31 siswa yang tidak mencapai standar ketuntasan sekolah, sehingga ada 25 siswa yang mencapai standar ketuntasan sekolah.

Berdasarkan data-data di atas diketahui persentase peningkatan hasil belajar adalah 21,97\%, sehingga dapat disimpulkan bahwa penerapan model pembelajaran yang dikembangkan pada uji coba terbatas dapat meningkatkan keterampilan menulis narasi siswa kelas II A SDN Kalijudan I Surabaya.

Di samping itu, hasil penilaian menulis karangan narasi siswa sebelum dan ketika penerapan model pemebelajaran yang dikembangkan pada uji coba luas dapat disajikan secara detail pada Tabel 7 berikut.

Tabel 7RekapitulasiHasil Tes Menulis Narasi (Uji Coba Luas)

\begin{tabular}{|l|l|l|l|l|l|l|}
\hline \multirow{2}{*}{ No } & \multirow{2}{*}{ Nama } & \multicolumn{2}{|c|}{ N } & \multirow{2}{*}{ PHB } & \multirow{2}{*}{ K } & \multirow{2}{*}{ KK (\%) } \\
\cline { 3 - 4 } & U1 & U2 & & & \\
\hline
\end{tabular}


Lilik Binti Mirnawati. Keefektifan Model Pembelajaran....

Jurnal Belajar Bahasa, ISSN 2502-5864, E-ISSN 2503-0329

Volume 4, No. 1, Februari 2019

\begin{tabular}{|c|c|c|c|c|c|c|}
\hline 1 & $\begin{array}{l}\text { Alvian Emir } \\
\text { Hakim }\end{array}$ & 60 & 83 & 23 & $\mathrm{~T}$ & \\
\hline 2 & $\begin{array}{l}\text { Aura Amira } \\
\text { Fathiyah }\end{array}$ & 70 & 82 & 12 & $\mathrm{~T}$ & \\
\hline 3 & $\begin{array}{l}\text { Azzam } \\
\text { Jevon } \\
\text { Abiyasa }\end{array}$ & 61 & 69 & 8 & - & \\
\hline 4 & $\begin{array}{l}\text { Dicky } \\
\text { Ibrahimovic } \\
\text { Arifin }\end{array}$ & 70 & 76 & 6 & $\mathrm{~T}$ & \\
\hline 5 & $\begin{array}{l}\text { Evander } \\
\text { Reynard } \\
\text { Prastyo }\end{array}$ & 58 & 81 & 23 & $\mathrm{~T}$ & \\
\hline 6 & $\begin{array}{l}\text { Feristan Dwi } \\
\text { Nurcahyono }\end{array}$ & 71 & 87 & 16 & $T$ & \\
\hline 7 & $\begin{array}{l}\text { Jessika Trias } \\
\text { Zarah }\end{array}$ & 61 & 87 & 26 & $T$ & \\
\hline 8 & $\begin{array}{l}\text { Jonathan } \\
\text { Izdihar } \\
\text { Fairuz }\end{array}$ & 56 & 72 & 16 & $T$ & \\
\hline 9 & $\begin{array}{l}\text { Kresna Tri } \\
\text { Suherman }\end{array}$ & 60 & 77 & 17 & $\mathrm{~T}$ & \\
\hline 10 & $\begin{array}{l}\text { Maulana } \\
\text { Pasha } \\
\text { Rabani P. }\end{array}$ & 61 & 75 & 14 & $\mathrm{~T}$ & \\
\hline 11 & $\begin{array}{l}\text { Muhammad } \\
\text { Fahmi Akbar }\end{array}$ & 70 & 76 & 6 & $T$ & \\
\hline 12 & $\begin{array}{l}\text { Muhammad } \\
\text { Khusnan }\end{array}$ & 56 & 89 & 33 & $\mathrm{~T}$ & \\
\hline 13 & $\begin{array}{l}\text { Muhammad } \\
\text { Sebastian } \\
\text { Saputra }\end{array}$ & 56 & 85 & 29 & $\mathrm{~T}$ & \\
\hline 14 & $\begin{array}{l}\text { Nayla } \\
\text { Carissa } \\
\text { Nasywah } \\
\end{array}$ & 56 & 73 & 17 & $\mathrm{~T}$ & \\
\hline 15 & $\begin{array}{l}\text { Nevan Noor } \\
\text { Faizin }\end{array}$ & 57 & 69 & 12 & - & \\
\hline 16 & $\begin{array}{l}\text { Oktaviola } \\
\text { Fahira } \\
\text { Nurmia }\end{array}$ & 61 & 90 & 29 & $\mathrm{~T}$ & 87,0968 \\
\hline 17 & $\begin{array}{l}\text { Oktaviona } \\
\text { Fahira } \\
\text { Nurmia }\end{array}$ & 62 & 67 & 5 & - & \\
\hline 18 & $\begin{array}{l}\text { Raffa } \\
\text { Alnando }\end{array}$ & 70 & 84 & 14 & $\mathrm{~T}$ & \\
\hline 19 & $\begin{array}{l}\text { Rafly } \\
\text { Miqdad } \\
\text { Aflah }\end{array}$ & 58 & 73 & 15 & $T$ & \\
\hline 20 & $\begin{array}{l}\text { Regina } \\
\text { Aprilia Putri } \\
\end{array}$ & 59 & 83 & 24 & $\mathrm{~T}$ & \\
\hline 21 & $\begin{array}{l}\text { Reyrit } \\
\text { Aisyah Pudji } \\
\text { A. }\end{array}$ & 64 & 90 & 26 & $\mathrm{~T}$ & \\
\hline 22 & $\begin{array}{l}\text { Rina } \\
\text { Rahmawati }\end{array}$ & 53 & 93 & 40 & $\mathrm{~T}$ & \\
\hline 23 & $\begin{array}{l}\text { Rio } \\
\text { Ferdinand }\end{array}$ & 57 & 86 & 29 & $\mathrm{~T}$ & \\
\hline 24 & $\begin{array}{l}\text { Risky Aditya } \\
\text { Noval Putra }\end{array}$ & 60 & 89 & 29 & $\mathrm{~T}$ & \\
\hline 25 & $\begin{array}{l}\text { Salsabila } \\
\text { Putri Amelia }\end{array}$ & 59 & 90 & 31 & $\mathrm{~T}$ & \\
\hline 26 & $\begin{array}{l}\text { Samudra } \\
\text { Hidayatulloh } \\
\text { Afif }\end{array}$ & 58 & 87 & 29 & $T$ & \\
\hline 27 & $\begin{array}{l}\text { Sashi Kirana } \\
\text { Gantari }\end{array}$ & 55 & 87 & 32 & $\mathrm{~T}$ & \\
\hline 28 & $\begin{array}{l}\text { Syavva } \\
\text { Aurelia } \\
\text { Nabila } \\
\text { Sibuea }\end{array}$ & 59 & 74 & 15 & $\mathrm{~T}$ & \\
\hline 29 & $\begin{array}{l}\text { Syiva Annisa } \\
\text { Hanif }\end{array}$ & 60 & 65 & 5 & - & \\
\hline 30 & $\begin{array}{l}\text { Tiara Shafa } \\
\text { Putri } \\
\text { Ardianty }\end{array}$ & 60 & 76 & 16 & $\mathrm{~T}$ & \\
\hline
\end{tabular}

\begin{tabular}{|c|c|c|c|c|c|}
\hline 31 & $\begin{array}{l}\text { Vemas } \\
\text { Hardiansyah } \\
\text { Ramadhan }\end{array}$ & 62 & 75 & 13 & $\mathrm{~T}$ \\
\hline & Jumlah & 1880 & 2490 & 610 & \\
\hline & Rata-rata & 60,645 & 80,323 & 19,67742 & \\
\hline \multicolumn{6}{|c|}{ Keterangan: } \\
\hline $\mathrm{N}$ & \multicolumn{5}{|l|}{ : Nilai } \\
\hline U1 & \multicolumn{5}{|l|}{ : Pre-test } \\
\hline U2 & \multicolumn{5}{|l|}{ : Post-test } \\
\hline $\mathrm{PH}$ & \multicolumn{5}{|c|}{ B : Peningkatan hasil belajar } \\
\hline K & \multicolumn{5}{|c|}{ : Ketuntasan } \\
\hline KK & \multicolumn{5}{|c|}{ : Ketuntasan klasikal } \\
\hline
\end{tabular}

Berdasarkan Tabel 7 diketahui bahwa hasil tes menulis uji coba yang dilakukan pada siswa kelas II SDN Kalijudan I Surabaya diperoleh data yaitu, nilai ratarata siswa pada pre-test ialah 60,65 dan terdapat 26 diantara 31 siswa yang tidak mencapai standar ketuntasan sekolah, sehingga yang mencapai standar ketuntasan minimal sebanyak lima anak. Setelah penerapan model pembelajaran yang dikembangkan, skor capaian nilai rata-rata siswa pada post-test menulis narasi ialah 80,32, dan terdapat 4 diantara 31 siswa yang tidak mencapai standar ketuntasan sekolah, sehingga ada 27 siswa yang mencapai standar ketuntasan sekolah.

Berdasarkan data-data di atas diketahui persentase peningkatan hasil belajar adalah 19,68\%, sehingga dapat disimpulkan bahwa penerapan model pembelajaran yang dikembangkan dapat meningkatkan keterampilan menulis siswa kelas II SDN Kalijudan I Surabaya.

Dari tabel dan penjelasan di atas, dapat disimpulkan bahwa model pembelajaran yang dikembangkan dapat meningkatkan keterampilan menulis siswa pada uji coba terbatas dan uji coba luas. Pada uji coba terbatas terdapat 
peningkatan hasil belajar sebesar $21,97 \%$, sedangkan pada uji coba luas terdapat peningkatan hasil belajar sebesar 19,68\%. Hal ini menunjukkan bahwa model pembelajaran yang dikembangkan efektif untuk meningkatkan keterampilan menulis siswa selama proses pembelajaran pada kelas II SDN Kalijudan I Surabaya.

\section{SIMPULAN}

Keefektifan model pembelajaran yang dikembangkan ditentukan oleh hasil pengamatan aktivitas siswa dan peninngkatan keterampilan menulis siswa. Hasil pengamatan aktivitas siswa mendapatkan persentase keaktifan siswa antara $81 \%-100 \%$ dengan kategori aktivitas siswa sangat baik. Peningkatan hasil belajar siswa pada uji coba terbatas adalah $21,97 \%$, sedangkan pada uji coba luas terdapat peningkatan hasil belajar sebesar 19,68\%. Hal ini menunjukkan bahwa model pembelajaran yang dikembangkan efektif untuk meningkatkan keterampilan menulis karangan narasi siswa kelas II SD.

\section{DAFTAR RUJUKAN}

Akbar, S. (2013). Instrument Perangkat Pembelajaran (Cetakan 1). Bandung: Remaja Rosdakarya.

Dalman. (2014). Keterampilan Menulis (4th ed.). Jakarta: PT. Raja Grafindo Persada. Retrieved from http://kin.perpusnas.go.id/DisplayDa ta.aspx?pld=97123\&pRegionCode $=U$
N11MAR\&pClientld=112

De Porter, B. and M. H. (2001). Quantum Learning. Membiasakan Belajar Nyaman dan Menyenangkan. Penerbit Kaifa.

Gorys Keraf. (2008). Argumentasi dan Narasi. Gramedia Pustaka Utama. Retrieved from http://www.gramedia.com/author_ detail.asp?id=ECAI3519

Hernowo. (2004). Quantum Writing: Cara Cepat nan Bermanfaat untuk Merangsang Munculnya Potensi Menulis. MLC.

KEMENDIKBUD. (2013). Kurikulum 2013 : Kompetensi Dasar. Jakarta: Kementerian Pendidikan dan Kebudayaan.

Mirnawati, L. B. (2017). The Improvement Writing Explanation Text through thelmplementation of Text Structure Mapping Strategy, (Ices), 122-126.

Nurgiyantoro, B. (2009). Penilaian dalam Pengajaran Bahasa dan Sastra (2nd ed.). Yogyakarta: BPFE.

Sugiyono. (2009). Metode Penelitian Pendidikan (Pendekatan Kuantitatif, Kualitatif, dan R\&D). Bandung: Alfabeta, CV Bandung.

Trianto. (2011). Mendesain Model Pembelajaran Inovatif Progresif dan Kontekstual. (T. Titik Triwulan \& Trianto, Eds.). Jakarta: Kencana Prenada Media Group.

Trianto. (2012). Mendesain Model Pembelajaran Inovatif - Progresif Konsep, Landasan dan Implementasinya pada Kurikulum Tingkat satuan Pendidikan ( KTSP). Jakarta: Kencana Prenada. Retrieved from http://36.89.24.67:82/layananjabar/opac/detail-opac?id=56654 